\title{
1. Introduction: the politics and practices of apartment living
}

For the first time in history, the majority of people now live in urban areas. For many of us that means we live in apartments. Apartment living requires that we try to get along with the people who live close to us in our building, but we also need to make decisions collectively about how the building we live in will be managed. What kind of a place do we want it to be? What behaviours are acceptable amongst our neighbours? How much do we want to spend on maintaining the building, and do we want to make any improvements? Occasionally everyone will agree, but most of the time they won't.

Why does this matter, and who cares? It matters because apartments are where we spend our time, make our homes, raise our families, invest our money, and experience important parts of our lives. They are where our parents, children, friends and colleagues live and apartment buildings make up an important part of the neighbourhoods we see and experience all around us.

Over the last decade I have spoken with apartment residents, owners and property managers about the challenges they face in living in and managing their properties. I have spoken with people whose health has suffered as a result of the stresses they have experienced in pursuing developers for defective work, challenging co-owners using their residential properties as hotels and standing up to neighbours bullying them to change their minds regarding a collective decision. I have spoken with people dedicated to improving their buildings for the benefit of all residents, including some who have given up after a series of crushing defeats. I have spoken with property managers, lawyers, developers, government officials and local academics about these issues in cities around the world. This book draws on interviews with over 100 people working with apartment developments in seven different countries.

In this book, I explore the politics and practices of apartment living. I look at the ways in which different housing markets, development practices, planning regimes, legal structures, and social and cultural norms affect people's everyday experiences of living in apartment buildings. As I talk through these issues, I will share insights from the people I have 
met. I spoke with people about their lives, their jobs, their concerns and their hopes. Some talked about homes, some about buildings, some about financial investments and some about professional practices. These insights are based on experiences from around the world (North America, Europe, Australasia, Asia and Africa). Despite these different perspectives and different origins, many of these experiences are shared. I found it astonishing to see how many issues are the same across all jurisdictions and fascinating to discover the different responses in different places. We need to understand these varied politics and practices of apartment living so that we can ensure that people can live better together in this urban century.

\section{THE URBAN CENTURY}

How well we respond to the challenge of housing rapidly growing urban populations has critical consequences for the viability of cities worldwide. In recent decades, this housing challenge has been met largely through the building of apartments. This has important implications for the experiences of city residents. The transition towards increased residential densities and its impact on people's lived experiences has been much discussed, along with the pros and cons of "urban consolidation" and "compact city" policies (Burton, 2000; Burton et al., 1996). Fuelling these ongoing debates is the fact that the precise impact of increased residential densities on people's experiences is difficult to determine because it is context specific. The outcomes for residents depend on the nature and quality of the built environment, the social relationships within buildings, and broader social and cultural expectations around apartment living. Debates around the efficacy of compact city policies have questioned the claims made in official planning documents about the social, economic and environmental benefits assumed to result from the implementation of these policies. Academic studies find evidence both for and against these claims in different contexts and using different methodologies (Bramley and Power, 2009; Breheny, 1995).

There is, however, another aspect to this shift toward the compact city that has received much less attention. This is the new forms of property ownership that have accompanied the widespread trend of apartment living in modern market economies, and which continues to reshape the future development of cities around the world. These forms of property ownership have had a major impact on the ways in which people experience apartment living and have important implications for social relations, household finances and the quality of the built environment. 
In particular, they impact upon the lived experiences of city residents and their relationships with their dwellings as homes. These new forms of ownership have many names. In this book, I call them condominiums.

\section{CONDOMINIUMS: A NEW(ISH) FORM OF PROPERTY OWNERSHIP}

What exactly do I mean by condominiums? I mean multi-unit and multiowned properties that house people. Multi-unit properties are buildings with multiple dwellings or units within them. They have existed for many hundreds of years, with examples dating from Roman times (Packer, 2012). Multi-owned properties are properties where each dwelling or unit can be owned separately. Those are a more recent invention, with comprehensive legislation governing the ownership of separate apartments within a building dating from the 1920s. Multi-owned multi-unit properties have played an important, but largely unrecognised, role in the promotion of home ownership in modern liberal democracies around the world over the last century. In the past, and especially across Europe (where the condominium was first introduced), a small number of landowners owned most of the land and rented it to the remaining population. This meant that apartment buildings were usually owned by a single landowner who either rented individual apartments out on short to medium terms (such as annually), or provided longer-term leases (ninety-nine years or more), while retaining ownership of the underlying land. These longer leases remain the predominant form of apartment "ownership" in England to this day. ${ }^{1}$ However, major social changes across Europe and elsewhere have produced substantial challenges to this entrenched system of land ownership in the hands of a few. My colleague, Associate Professor Cathy Sherry, put this succinctly:

The Industrial Revolution, the rise of the middle classes, universal enfranchisement, the development of modern liberal democratic states, WWI, the Depression, WWII, the rise of communism (in short modern Western history) culminated in ... societies that supported the idea of secure home ownership for the masses. It was no longer politically acceptable for a narrow, ruling class to control the majority of land. (Sherry, 2016)

Home ownership was an important stabilising force in an unstable world and increasingly seen as essential to ensure economic productivity and stability in other parts of society (Ronald, 2009). The difficulty was that in the inter-war and post-World War II era, providing ownership of houses with land was not feasible in many urban areas, where populations were 
increasing rapidly and land was in short supply. There was a need then to find a way to enable people to own their own apartments. It was in this context that the modern condominium came to be.

There are many different ways in which the ownership of an apartment building can be divided. All attempts at categorising these are ultimately flawed because so many of these arrangements are actually hybrid approaches. However, as a starting point, it is helpful to draw upon van der Merwe's (1994) description of the difference between "unitary" and "dualistic" forms of apartment ownership. Broadly, in a unitary system a company or co-operative owns the apartment building as a whole, and individuals hold shares in the organisation that owns the property. This gives them the right to live in or rent out a particular apartment in the building. The most common example of unitary systems around the world are co-operatives. In a dualistic system, each apartment unit within a building is owned separately and individually, and the owners of the apartments also own collectively the common property (including infrastructure and amenities). In this sense, there are two layers of ownership; the collectively owned property (the land, buildings and common areas) and the individually owned property of the interior of each apartment. Common examples of dualistic systems around the world are condominiums and strata title

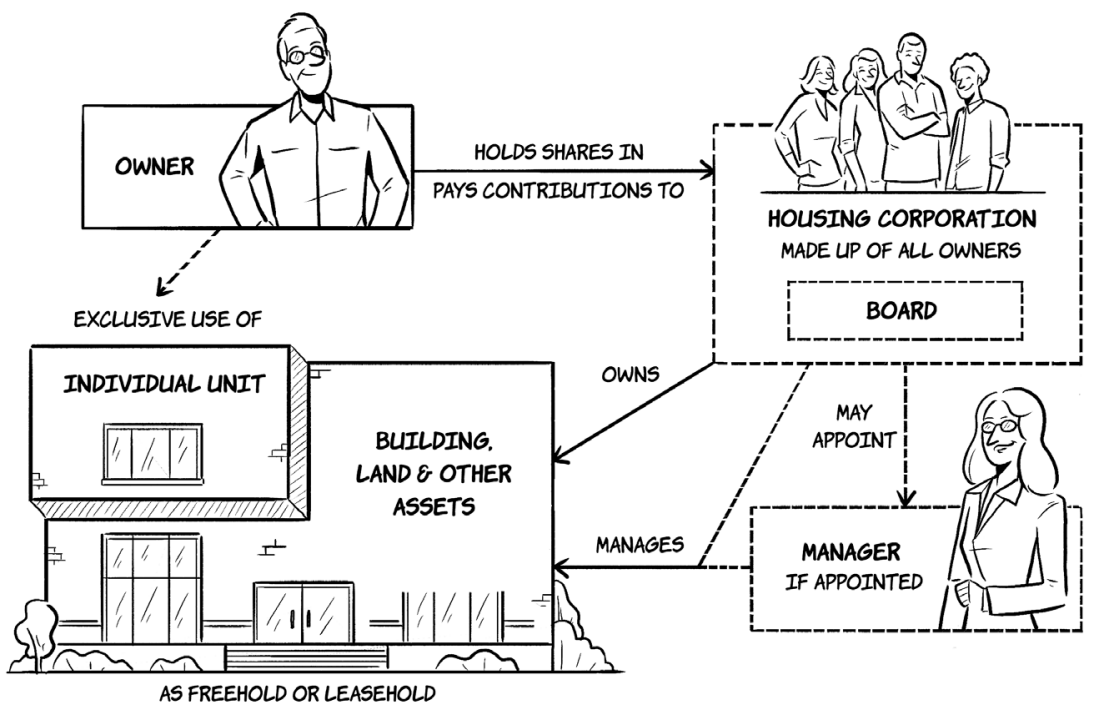

Source: Image by Dawid Szymczyk, dawidszymczyk.com.

Figure 1.1 Generic unitary system 


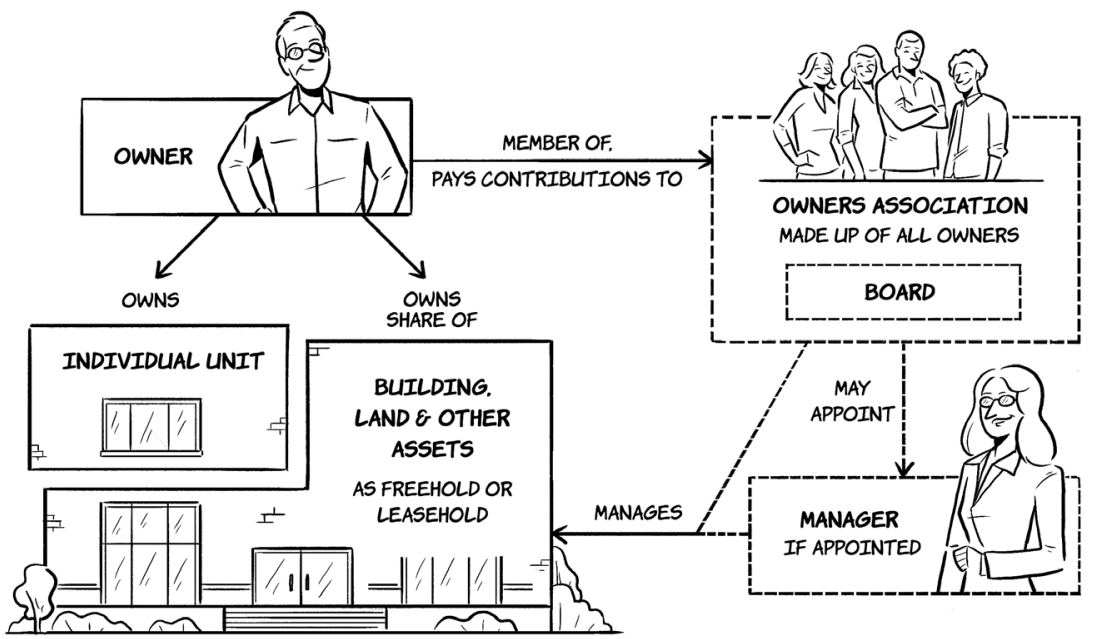

Source: Image by Dawid Szymczyk, dawidszymczyk.com.

\section{Figure 1.2 Generic dualistic system}

developments. Figures 1.1 and 1.2 outline the generic characteristics of unitary and dualistic ownership systems.

In this book, 1 focus primarily on dualistic systems of ownership, where ownership of the individual unit is separate from the collective ownership of the buildings and grounds. This focus reflects the fact that the dualistic model is the most common form of apartment ownership in most of the countries I studied, and in some countries (for example, the United States of America (USA) and Australia) has taken over as the dominant form from older unitary systems. There are some notable exceptions such as Hong Kong, where apartments are owned under tenancy in common arrangements whereby owners own an undivided share in their buildings, similar to a unitary system. Still, apartment ownership in Hong Kong operates to all intents and purposes in the same way as condominium ownership operates elsewhere. In England, the system of leasehold apartment ownership further complicates the story, introducing yet another model that in law is very different from both the unitary and dualistic systems outlined above. In practice, however, the English ownership model also has the potential to operate as though it were a condominium (see Chapter Two for a more detailed discussion).

Not all multi-unit properties are condominiums according to my definition. Apartment buildings that are owned entirely by one person or organisation (such as a private landlord, government, or community 
housing company) and rented out are not condominiums because they are not multi-owned. But many condominiums include rented units and it is common across the jurisdictions covered in this book for condominiums to house a mix of owner occupiers and renters. This is one of the things that makes researching condominiums so interesting. In Sydney, where I live, there are more renters living in condominiums than owner occupiers (Australian Bureau of Statistics, 2016) and if you are renting an apartment in that city, you are most likely living in a condominium.

Not all multi-owned properties are condominiums according to my definition either. Developments that are made up of detached houses and private common areas (such as parks, club houses and roads) are not condominiums, because they are not multi-unit properties. However, these types of developments, variously known as gated communities, master-planned estates and common interest developments, might have condominiums within them. For example, one of the oldest masterplanned estates in Sydney, Liberty Grove, includes multi-owned apartment buildings within it, each with its own governance structure that sits below that of the wider development.

Condominiums then are multi-unit properties with multiple owners. As joint owners, they are jointly responsible for the management and upkeep of their buildings. On purchasing an apartment in the development, owners automatically join a legal entity that has responsibilities for the upkeep of the property and the proper management of the finances. This entity is usually in the form of an owners corporation and its actions are governed by legislation. In many countries, formation of an owners corporation and membership in it is automatic and mandatory for all property owners, although there are some exceptions (see Chapter Two). These owners corporations usually operate as an additional tier of urban governance, below that of municipal government, in that they collect taxes (levies or contributions), set rules governing behaviour and elect representatives to make decisions on their behalf (Easthope, 2009). Condominiums are very important institutions that shape urban life, although they are seldom recognised as such. The difference between condominiums and other tiers of governance is that they are usually run by unpaid volunteers, who can be tasked with managing annual budgets that run into millions of dollars. The requirement on condominium owners to manage their properties collectively often results in tension, but it also opens up opportunities for collective support and collective action. This relatively new form of property ownership has important implications for social relations, household finances and the quality of the built environment. 


\section{WHAT IS SO SPECIAL ABOUT CONDOMINIUM LIVING?}

People often ask how condominiums are different from any other type of housing. I have three answers to this question. The first and perhaps most obvious answer is that people who live in multi-unit properties live closer to their neighbours than people who live in detached houses and usually have a larger number of immediate neighbours. This means that there are more people close by who can potentially annoy you and whom you can potentially annoy. This is the case for all multi-unit properties, whether or not they are multi-owned. The other two reasons apply particularly to multi-unit and multi-owned properties. The second answer is that each of the properties in a multi-unit development is interdependent. It is not usually possible to demolish and rebuild an apartment without demolishing, or at the very least seriously damaging, the building as a whole. Similarly, more minor renovations or remodelling of a single unit can have an impact on other parts of the building. This means that condominium owners do not and cannot have the same autonomy over what they do in and to their properties as other property owners. The third answer, which is related to the second, is that condominium living necessitates joint decision-making, and that detailed and prescriptive rules governing how these decisions can be made are in place around the world. Condominiums bring to the surface the tensions that exist in modern cities between individual rights and collective responsibilities. This is why they are so fascinating to study and essential to understand.

\section{THE POLITICS AND PRACTICES OF APARTMENT LIVING}

When I talk about the politics and practices of apartment living, I am talking about the micro-politics and everyday practices that occur within, and in relation to, condominium developments. At their core is the constant tension between the private rights of individual owners and the collective rights of all owners (and associated rights of renters), and how these tensions are negotiated formally and informally.

While home ownership is often associated with ideas of control and eminent domain, condominium owners are seldom in a position to make individual decisions about their property and must negotiate and compromise with co-owners. Renters usually have even less of a say about what happens to their homes. The ways in which control is negotiated and exercised in this context is a central focus of this book. Whether people are, or 
feel that they are, in control of the places in which they live is central to their psychological wellbeing and their relationships with their dwellings as homes (Blunt and Dowling, 2006; Clapham, 2010; Saunders, 1989). The reason people are so invested in what happens in condominiums is that their apartments are not only important financial assets, they are also places where they live and make their homes.

As well as owners and renters, there are also many other stakeholders who can be involved in the life of condominium buildings. As my colleague and I have previously noted:

The range of stakeholders involved in a typical strata scheme [condominium] - including resident owners, investor owners, tenants, commercial owners and businesses, building managers and others, including mortgage lenders - raises the potential for significant conflicts over intentions and aspirations. The potential for conflict is growing as the size and complexity of strata [condominium] developments, especially the requirement for mixed use development in many urban renewal areas, increases. (Easthope and Randolph, 2018, p. 95)

This micro-politics of apartment living is strongly influenced by local, regional, national and global socio-economic and political forces, including housing markets, development practices, planning regimes, legal structures and social and cultural norms. These wider forces shape the interests and experiences of the essentially private communities within condominium developments and their role in, and interactions with, the broader public life of cities. They also help explain the great diversity across condominiums in terms of the location, quality and size of the buildings themselves, the socio-economic and tenure mix of the residents who live in them, and the extent to which they are managed efficiently and democratically. The condominiums that I discuss in this book range from apartment buildings in disadvantaged areas that predominantly house poorer private renters to high end luxury developments with property management teams providing hotel-level service to their wealthy residents. Inequity in the city is clearly manifest at the local level of the condominium.

Indeed, while the condominium was developed in the context of liberal democracies and the encouragement of home ownership, it has morphed over time into something quite different. Rosen and Walks (2015, pp. 165-6) express this well in talking about the impact of high rise condominium development in the city of Toronto:

As condo-ism has wielded increasing power over urban development patterns and has become an integral part of the urban fabric - by providing jobs, public benefits and a whole new style of living - the sheer size and wealth of the 
developers has given them increasing control over both the urban development process and, in turn, the condo narrative. Condo-ism has clearly served as an agent of urban redevelopment and transformation, regardless of its potential drawbacks - particularly vis-à-vis transparency and social equity.

Debates about the relative value of housing as a commodity to be bought and sold on the one hand, and its value as a place to live on the other, are well established in the academic literature (Harvey, 2014). The condominium has increasingly become a vehicle for the promotion of the commodity value of housing, sometimes at the expense of its value as a place to live. Property investors often prefer apartments because maintenance responsibilities and costs are comparatively low, and they can buy into good locations more cheaply than for detached, stand-alone housing (Altmann, 2014).

The central importance of condominium properties to the global flow of investment capital in and between cities such as New York, Hong Kong, London, Vancouver and Sydney is well documented, as are the implications for house prices in these cities and the ability of local residents to purchase apartments in which to live (Liao et al., 2015; Surowieki, 2014). However, in many cities, local domestic investors have an even greater impact on the housing market, not only in terms of the price of properties, but also their design and quality (Sharam et al., 2015). Evidence of investment properties being left empty as they accrue capital gains (McKenny and Ting, 2018), poor alignment between the design of apartments and the needs of the people who will ultimately live in them (Easthope and Tice, 2011), and rampant building defects (for example, Agola and Kashiyani, 2015; Christudason, 2007; de Silva, 2011; Hai, 2007; Murphy, 2011; Noble-Allgire, 2009) all point to apartment markets being distorted by capital market incentives at the expense of the use value of those properties.

An associated trend is the increasing inequality evident in cities between those who own property and those who do not, with sizeable groups being excluded from property ownership and hence both the capital and use benefits it affords. In Australia, for example, this is compounded by tax incentives that effectively subsidise property ownership both for owner occupiers (through an exemption on capital gains tax) and investor owners (by allowing tax offsets for rental losses against regular income through negative gearing), while leaving non-owners to fend for themselves in a largely unregulated private rental system (Easthope, 2014). The inequity of this situation has not gone unnoticed, especially now that the middle classes are also increasingly finding themselves excluded from property ownership (Harrison, 2017). 
The broader impact of these inequities is starkly evident in wide disparities between different groups of apartment residents in Australian cities. My colleagues (Randolph and Tice, 2013) have identified five major submarkets of apartment residents in the two largest Australian cities (Sydney and Melbourne), who have very different housing experiences and who live in different parts of the city. These five submarkets are:

- The "apartment elite" (middle-aged professionals on high salaries who are concentrated in the inner suburbs and who mostly own their apartments).

- Those "achieving education" (students concentrated in the inner and middle suburbs who rent).

- The "economically engaged" (singles and dual income households with no kids who live across the metropolitan area and mostly rent, with some purchasing their apartment).

- The "residentially retired" (older residents often living alone, who own across the metropolitan area).

- The "battlers" (low-income families who are concentrated in the middle and outer suburbs and who mostly rent).

In Sydney, the "battler" group is the largest submarket of the condominium population. In Melbourne it is the "achieving education" group. What is happening in these Australian cities is not unusual. Similar trends of rising inequality and socio-spatial polarisation are occurring in other cities around the world (Florida and Mellander, 2016; Musterd et al., 2017) and are reflected in the profiles of condominium residents. In Toronto, Lehrer and Wieditz $(2009$, p. 141) point to the role that new condominium developments can play in increasing spatial inequality in cities. They describe three distinct cities in Toronto: "the constant city of the rich, the shrinking city of middle-income households, and the growing city of concentrated poverty" (ibid.). They also argue that "condominium towers are a new form of gentrification that contributes to the spatial trifurcation of the city" (ibid.).

Inequities of this kind are evident not only at the metropolitan scale, but can also play out within individual condominiums. This is most noticeable in the inequities between owner occupiers and renters regarding the influence they can have over the building in which they live. It is also evident in other ways such as through disputes over paying for maintenance and improvements between older long-term owner occupiers with constrained incomes and newer owners who have paid significantly more for their apartments and are interested in property upgrades. These types of local-level inequities and power-plays, and their 
impact on condominium living at the building scale, are discussed in more depth later in the book.

\section{STRUCTURE OF THE BOOK}

Throughout this book, I will explore the politics and practices of apartment living in different countries and in different contexts. Chapter Two, "International condominium systems", offers a historical description of condominium systems around the world and information about the seven countries that feature in the book: the USA, Canada, Australia, England, Singapore, Hong Kong (China) and South Africa.

The remainder of the book is structured around the lifecycle of an apartment building. In order to properly understand the politics and practices of apartment living in different contexts, we need to understand all stages of the life of an apartment development. For example, to understand why an apartment building is uncomfortable or difficult to manage, we must be aware of how it was built and how its governance structures were set up. It is also important to consider how the politics and practices of apartment living can change over time as people come and go and the building ages.

Chapter Three, "Development", deals with the question of what is built and why. It discusses how decisions are made about what to build, as well as factors that influence the quality of new apartment buildings. Chapter Four, "Handover", deals with the period during which the developer hands over control to subsequent owners of the development. It considers how the set-up of governance structures by the developer can impact both positively and negatively on the subsequent management of the buildings, and how the ongoing control of a developer (or their subsidiaries) long after a development's completion can affect the subsequent residents. Chapter Five, "Early years", considers the first ten years of a development and discusses common challenges faced by young apartment buildings, as well as what can be done in this early period to put a condominium on a positive course. This is followed by Chapter Six, "Later years", which discusses the challenges and opportunities posed by established apartment buildings. "Redevelopment" is the subject of Chapter Seven, which focuses on the issue of control in decisions to redevelop condominiums.

The book concludes by arguing that the fact that condominiums have been regarded as creators of social and economic polarisation (Kern, 2014 , p. 3) has more to do with the political, economic and social systems in which condominiums were introduced and in which they operate than it does with the condominium ownership and governance systems 
themselves. While there are many challenges associated with the politics and practice of condominium living, the existence of condominiums as major institutions and an additional tier of urban governance provides a huge, but largely untapped, potential for positive change in modern cities.

\section{NOTE}

1. Although with some significant changes, discussed further in Chapter Two.

\section{REFERENCES}

Agola J.D. and Kashiyani B.K. (2015) Conceptual study on construction defects and its solution. International Journal of Advanced Research in Engineering, Science and Management 1(6), 1-7.

Altmann E. (2014) Apartments, co-ownership and sustainability: Implementation barriers for retrofitting the built environment. Journal of Environmental Policy and Planning 16(4), 437-57.

Australian Bureau of Statistics (2016) Census of population and housing. Canberra: Australian Bureau of Statistics. Available at: http://www.abs.gov.au/websitedbs/ D3310114.nsf/Home/Census?OpenDocument\&ref=topBar (accessed 11 June 2018).

Blunt A. and Dowling R. (2006) Home, Abingdon, UK: Routledge.

Bramley G. and Power S. (2009) Urban form and social sustainability: The role of density and housing type. Planning and Design 36, 30-48.

Breheny M. (1995) The compact city and transport energy consumption. Transactions of the Institute of British Geographers 20(1), 81-101.

Burton E. (2000) The compact city: Just or just compact? A preliminary analysis. Urban Studies 37(11), 1969-2006.

Burton E., Jenks M. and Williams K. (1996) The Compact City: A Sustainable Urban Form?, London: E \& FN Spon.

Christudason A. (2007) Defects in common property of strata developments in Singapore: Representative actions against developers. Structural Survey 25(3/4), 306-18.

Clapham D. (2010) Happiness, well-being and housing policy. Policy and Politics $38(2), 253-67$.

De Silva N. (2011) Promoting the facilities management profession in the project development phase of high-rise buildings in Sri Lanka. Built-Environment Sri Lanka 9-10(1-2), 37-44.

Easthope H. (2009) The fourth tier of governance: Managing the future of our cities. Paper presented at the State of Australian Cities National Conference, Perth, WA, 24-27 November. Available at: http://apo.org.au/node/60112 (accessed 30 July 2018).

Easthope H. (2014) Making a rental property home. Housing Studies 29(5), 579-96.

Easthope H. and Randolph B. (2018) Experiencing density: The implications of 
strata titling for urban renewal in Australian cities. In: Ruming K.J. (ed.) Urban Regeneration in Australia: Policies, Processes and Projects of Contemporary Urban Change, Abingdon, UK: Routledge, pp. 94-108.

Easthope H. and Tice A. (2011) Children in apartments: Implications for the compact city. Urban Policy and Research 29(4), 415-34.

Florida R. and Mellander C. (2016) The geography of inequality: Difference and determinants of wage and income inequality across US metros. Regional Studies 50(1), 79-92.

Hai D.T. (2007) Current status of existing condominium buildings in Vietnam: Common problems, main causes and proposed maintenance strategies. Paper presented at the International Conference on Sustainable Architectural Design and Urban Planning, Hanoi Architectural University, 15-16 May.

Harrison J. (2017) Letter to the Editor: City's heart crushed by political and personal greed. The Sydney Morning Herald, 14 May. Available at: https://www. smh.com.au/national/welcome-to-the-real-world-of-paye-tax-20170514-gw4iry. html (accessed 17 September 2018).

Harvey D. (2014) Seventeen Contradictions and the End of Capitalism, London: Profile Books.

Kern L. (2014) Sex and the Revitalized City: Gender, Condominium Development, and Urban Citizenship, Vancouver: UBC Press.

Lehrer U. and Wieditz T. (2009) Condominium development and gentrification: The relationship between policies, building activities and socio-economic development in Toronto. Canadian Journal of Urban Research 18(1), 140-61.

Liao W.-C., Zhao D., Lim L.P. and Wong G.K.M. (2015) Foreign liquidity to real estate market: Ripple effect and housing price dynamics. Urban Studies 52(1), $138-58$.

McKenny L. and Ting I. (2018) Thousands of empty homes adding to Sydney's housing crisis, experts say. The Sydney Morning Herald, 29 March. Available at: http://www.smh.com.au/nsw/thousands-of-empty-homes-adding-to-sydneyshousing-crisis-experts-say-20160323-gnpc52.html (accessed 17 November 2017).

Murphy C. (2011) Building control changes: The on-going battle against the leaking building. Architectural Science Review 54(2), 157-63.

Musterd S., Marcińczak S., van Ham M. and Tammaru T. (2017) Socioeconomic segregation in European capital cities: Increasing separation between poor and rich. Urban Geography 38(7), 1062-83.

Noble-Allgire A.M. (2009) Notice and opportunity to repair construction defects: An imperfect response to the perfect storm. Real Property, Trust and Estate Law Journal 43(4), 729-96.

Packer J.E. (2012) Housing and population in imperial Ostia and Rome. Journal of Roman Studies 57(1-2), 80-95.

Randolph B. and Tice A. (2013) Who lives in higher density housing? A study of spatially discontinuous housing sub-markets in Sydney and Melbourne. Urban Studies 50(13), 2661-81.

Ronald R. (2009) The Ideology of Home Ownership: Homeowner Societies and the Role of Housing, Basingstoke, UK and New York: Palgrave Macmillan.

Rosen G. and Walks A. (2015) Condo-ism as a way of urban life. In: Bagaeen S. and Uduku O. (eds) Beyond Gated Communities, London: Routledge, pp. $154-69$.

Saunders P. (1989) The meaning of "home" in contemporary English culture. Housing Studies 4(3), 177-92. 
Sharam A., Bryant L. and Alves T. (2015) Making Apartments Affordable: Moving from Speculative to Deliberative Development, Melbourne: Swinburne University of Technology.

Sherry C. (2016) E-mail correspondence, 23 August.

Surowieki J. (2014) Real estate goes global. The New Yorker, The Financial Page, 26 May. Available at: https://www.newyorker.com/magazine/2014/05/26/realestate-goes-global (accessed 17 November 2017).

Van der Merwe C.G. (1994) Apartment ownership. In: Yiannopoloulos A.N. (ed.) International Encyclopedia of Comparative Law, Property and Trust, Tübingen: Mohr, p. 42. 